\title{
Antioxidant enzymes in liver of dab Limanda limanda from the North Sea
}

\author{
D. R. Livingstone ${ }^{1}$, S. Archibald ${ }^{1}$, J. K. Chipman ${ }^{2}$, J. W. Marsh ${ }^{2}$ \\ ' NERC Plymouth Marine Laboratory, Citadel Hill, Plymouth, Devon PL1 2PB, United Kingdom \\ ${ }^{2}$ School of Biochemistry, University of Birmingham, Edgbaston, Birmingham B15 2TT, United Kingdom
}

\begin{abstract}
During the Bremerhaven Workshop, antioxidant enzyme activities were measured in liver of dab Limanda limanda from 7 stations along a gradient of decreasing organic and metal pollution from Heligoland to the Dogger Bank, and at 3 stations close to and distant from an abandoned drilling site, in the German Bight of the North Sea. Activities of catalase and glutathione peroxidase were higher near to Heligoland, consistent with higher levels of pollution. Catalase and superoxide dismutase (SOD) activities were also high at the Dogger Bank, but the reasons for this are unknown. SOD activity showed a distinct U-shaped profile along the contaminant gradient, indicating effects of factors other than pollution alone. Putative DT-diaphorase (dicumarol-inhibitable NADPH-dependent dichlorophenolindophenol [DCPIP] reductase) activity was higher near the drilling site, but the characteristics and significance of this enzyme are not well understood. The case for using antioxidant enzymes as biomarkers for environmental oxidative stress is therefore as yet unproven, but merits further study.
\end{abstract}

\section{INTRODUCTION}

Most molecular oxygen in aerobic organisms undergoes tetravalent reduction to water. However, partial reduction by various endogenous processes resuits in the constant production of small amounts of highly reactive oxygen species (so-called oxyradicals), including the superoxide anion radical $\left(\mathrm{O}_{2}^{-}\right.$, from univalent reduction) and hydrogen peroxide $\left(\mathrm{H}_{2} \mathrm{O}_{2}\right.$, from bivalent reduction) (Ames 1989, Halliwell \& Aruoma 1991). Oxyradical production can be increased by exposure to foreign compounds (xenobiotics): potential sources of pollutant-stimulated oxyradical production include redox reactions with transition metals (e.g. $\mathrm{Fe}, \mathrm{Cu}, \mathrm{Ni}$ and $\mathrm{Co}$ ) (Aust et al. 1985, Halliwell \& Aruoma 1991) and organic free radicals (Winterbourn 1987), induction of cytochrome P450s (Premereur et al. 1986), and redox cycling of xenobiotics such as quinones, aromatic amines and nitroaromatics (Kappus 1986). The many toxic molecular effects of oxyradicals include changes in redox balance and intracellular free $\mathrm{Ca}^{2+}$ levels, enzyme inactivation, lipid peroxidation, cytoskeletal disrup- tion, DNA damage and cell death (Borg \& Schaich 1984, Ames 1989). In mammals, such events are involved in a number of diseases, including cancer. The production and potential effects of oxyradicals are held in check by antioxidant defences, including specialized antioxidant enzymes. These enzymes can be induced by pro-oxidant conditions (increased oxyradical generation), but can also be affected by other factors, including diet, age and inhibition by certain xenobiotics (see 'Discussion').

Pollutants may also stimulate oxyradical generation in fish (Di Giulio et al. 1989, Livingstone et al. 1990, Winston 1991, Winston \& Di Giulio 1991), though much less information exists about pro-oxidant and antioxidant processes in aquatic organisms than in mammals. Oxidative DNA lesions have been detected in neoplastic livers of the English sole Parophrys vetulus from a polluted environment (Malins et al. 1990), and were produced in liver, kidney and blood of juveniles of this species following intramuscular injection of the redox cycling nitroaromatic, nitrofurantoin (Nishimoto et al. 1991). Additionally, elevations in hepatic and other tissue antioxidant enzyme activities 
(albeit somewhat variable) have been observed in several fish species following experimental exposure to metals and organic xenobiotics (see 'Discussion').

The dab Limanda limanda is an important target species for pollution monitoring in the North Sea (Rijnsdorp et al. 1992). Hepatic antioxidant enzyme activities were measured as potential biomarkers of oxidative stress in fish from a chemical contaminant gradient in the German Bight (from Heligoland to the Dogger Bank) and in the vicinity of an abandoned drilling site of the Dutch coast. The enzymes assayed were superoxide dismutase (SOD; EC 1.15.1.1), catalase (EC 1.11.1.6), selenium-dependent glutathione peroxidase (GPX; EC 1.11.1.9) and microsomal NADPH-dependent DT-diaphorase (NAD(P)H: quinone oxidoreductase; EC 1.6.99.2). In mammals exposed to certain xenobiotics such as polynuclear aromatic hydrocarbons and polychlorobiphenyls (PCBs), the induction of DT-diaphorase is genetically linked to that of cytochrome P4501A1 (Nebert et al. 1990), measurements of the latter having been extensively used in fish as a specific indicator of the impact of organic pollution (Jimenez \& Stegeman 1990, Jimenez et al. 1990).

\section{MATERIALS AND METHODS}

Sampling stations, fish and tissue collection. The locations and other details of the stations are given in Stebbing \& Dethlefsen (1992). Contaminant distribution is summarised in Table 1 and in the 'Discussion'. Dab were taken at Stns $1,3,5,6,7,8$ \& 9 along the contaminant gradient, and at Stns A, G \& R 0,5 and 15 $\mathrm{km}$ from the drilling site). Mature female fish of similar size were used, ranging in length from $21.7 \pm 0.6 \mathrm{~cm}$ (Stn 9) to $24.2 \pm 0.6 \mathrm{~cm}$ (Stn 1) (mean \pm SEM). Fish were sacrificed as described by Renton \& Addison (1992) and the livers dissected out, weighed and either used immediately, or stored frozen at $-70^{\circ} \mathrm{C}$ prior to analysis.

Preparation of liver subcellular fractions. The livers of individual fish were used ( $n=4$ to 18 for German Bight stations and 3 to 6 for drilling site stations). Fresh tissues (Stns 3, 5, $7 \&$ \& ) were homogenized on board ship and frozen ones (Stns 1, 6, 7, 8 \& 9) at the laboratory. All procedures were carried out at $4{ }^{\circ} \mathrm{C}$. Tissues were homogenized in $0.1 \mathrm{M} \mathrm{KH}_{2} \mathrm{PO}_{4} / \mathrm{K}_{2} \mathrm{HPO}_{4} \mathrm{pH} 7.5$ containing $0.15 \mathrm{M} \mathrm{KCl}$ and $1 \mathrm{mM}$ EDTA (w:v $1: 3$ to 1:10) using a Potter-Elvehjem homogenizer. The homogenate was centrifuged at $10000 \times g$ for $20 \mathrm{~min}$, and the resulting supernatant at $100000 \times g$ for $60 \mathrm{~min}$. Aliquots of the $10000 \times \mathrm{g}$ and $100000 \times \mathrm{g}$ pellets were resuspended in reduced volumes of homogenization buffer. SOD was assayed in the 10000 $\times g$ supernatant, which was first passed down a Sephadex G-25 column (PD-10 column; bed volume $9 \mathrm{ml}$, equilibrated and eluted with homogenization buffer) to remove the low molecular weight fraction (MW $\leq 5000)$ which may interfere in the SOD assay. GPX was assayed in the $100000 \times g$ supernatant (cytosol) and catalase in both the $0-10000 \times g$ pellet and G-25-treated $10000 \times g$ supernatant subcellular fractions. DT-diaphorase was assayed on microsomes $\left(100000 \times g\right.$ pellet) after storage overnight at $-20^{\circ} \mathrm{C}$.

Biochemical assays. Sodium azide, reduced glutathione (GSH), horse heart cytochrome $c_{\text {, }}$ hypoxanthine, $\mathrm{H}_{2} \mathrm{O}_{2}$, reduced $\mathrm{B}$-nicotinamide adenine dinucleotide phosphate (NADPH), dichlorophenolindophenol (DCPIP), dicumarol (3,3'-methylene-bis(4hydroxycoumarin)), glutathione reductase (EC 1.6.4.2) and xanthine oxidase (EC 1.2.3.2) were obtained from Sigma Chemical Co., UK. All other chemicals were AnalaR grade (BDII Ltd., UK) or equivalent, and the PD-10 Sephadex G-25 columns were from PharmaciaLKB, UK.

Enzyme assays were carried out in duplicate, at $25^{\circ} \mathrm{C}$, on a Kontron UVIKON 810 dual beam spectrophotometer. Activities were linear with time (catalase, GPX, DT-diaphorase) and sample concentration over a 5-fold range, and were performed as described by Livingstone et al. (1990). Catalase activity

$$
2 \mathrm{H}_{2} \mathrm{O}_{2}=2 \mathrm{H}_{2} \mathrm{O}+\mathrm{O}_{2}
$$

was measured by the decrease in absorbance at $240 \mathrm{~nm}$ due to $\mathrm{H}_{2} \mathrm{O}_{2}$ consumption (absorbance $40 \mathrm{~cm}^{-1}$ $\mathrm{M}^{-1}$; reaction conditions $50 \mathrm{mM} \mathrm{KH}_{2} \mathrm{PO}_{4} / \mathrm{K}_{2} \mathrm{HPO}_{4} \mathrm{pH}$ 7.0, $50 \mathrm{mM} \mathrm{H}_{2} \mathrm{O}_{2}$ ). SOD activity

$$
2 \mathrm{O}_{2}^{-}+2 \mathrm{H}^{+}=\mathrm{H}_{2} \mathrm{O}_{2}+\mathrm{O}_{2}
$$

was measured by the degree of inhibition of the reduction of cytochrome $c$ (monitored at $550 \mathrm{~nm}$ ) by $\mathrm{O}_{2}^{-}$generated by the xanthine oxidase/hypoxanthine reaction (McCord \& Fridovich 1969). One unit of SOD activity is defined as that amount of sample causing $50 \%$ inhibition of cytochrome $c$ reduction under the standard conditions of the assay $\left(43 \mathrm{mM} \mathrm{KH} \mathrm{KHO}_{2} /\right.$ $\mathrm{K}_{2} \mathrm{HPO}_{4} \mathrm{pH} 7.8,0.1 \mathrm{mM}$ EDTA, $50 \mu \mathrm{M}$ hypoxanthine, $5.7 \mathrm{mU}$ xanthine oxidase, $10 \mu \mathrm{M}$ cytochrome $c)$. GPX activity

$$
\mathrm{H}_{2} \mathrm{O}_{2}+2 \mathrm{GSH}=\mathrm{GSSG} \text { [oxidised glutathione] }+2 \mathrm{H}_{2} \mathrm{O}
$$

was measured by linking the reaction to the reduction of GSSG catalysed by glutathione reductase (absorbance $6.2 \mathrm{~cm}^{-1} \mathrm{mM}^{-1}$; reaction conditions $65 \mathrm{mM}$ $\mathrm{KH}_{2} \mathrm{PO}_{4} / \mathrm{K}_{2} \mathrm{HPO}_{4} \mathrm{pH}$ 7.5, $2 \mathrm{mM}$ GSH, $1 \mathrm{mM} \mathrm{NaN}$, 1 unit glutathione reductase, $0.12 \mathrm{mM}$ NADPH, $2 \mathrm{mM}$ $\mathrm{H}_{2} \mathrm{O}_{2}$ ). In mammals the assay is specific for the activity of selenium-dependent GPX, as opposed to the sum of this and the GPX activity of glutathione S-transferases 
(Lawrence \& Burk 1976). DT-diaphorase prevents redox cycling of quinones by catalysing their 2-electron reduction to hydroquinones. Its activity was measured as the dicumarol-inhibitable part of NADPH-dependent DCPIP reductase activity. Reduction of DCPIP was followed at $600 \mathrm{~nm}$ in the absence and presence of $100 \mu \mathrm{M}$ dicumarol added in $0.15 \% \mathrm{w} / \mathrm{v} \mathrm{NaOH}$ (absorbance $21 \mathrm{~cm}^{-1} \mathrm{mM}^{-1}$; reaction conditions $50 \mathrm{mM}$ Tris- $\mathrm{HCl} \mathrm{pH} 7.6,0.3 \mathrm{mM}$ NADPH, $40 \mu \mathrm{M}$ DCPIP). The basis of the assay is that DCPIP-reduction is a measure of total reductase activity, including that of DTdiaphorase, and dicumarol is a specific inhibitor of DTdiaphorase (Benson et al. 1980). However, given that the concentration of dicumarol required to completely inhibit DT-diaphorase depends on the affinity of the enzyme for the co-substrates (Preusch et al. 1991), and the characteristics of dicumarol-inhibition have not yet been established for any purified fish DT-diaphorase, the activity must be regarded as putative. Protein was measured by the method of Lowry et al. (1951) using bovine serum albumin as standard.

Enzyme activities were measured in the subcellular fractions in which they were concentrated (see previous section), in terms of either activity per $g$ wet weight or per mg protein. Catalase activity was dis- tributed between the $10000 \times g$ pellet (probably due to intact peroxisomes) and $10000 \times g$ supernatant (due to either broken peroxisomes and/or cytosolic catalase), and the sum of the two was calculated. With the exception of GPX, enzyme activities were similar in fresh and frozen tissues, and the pooled data were used in the calculations. GPX activity was increased significantly $(p<0.05)$ by freezing the tissue: activities of fresh and frozen tissue, respectively, were $2.29 \pm$ 0.15 and $3.86 \pm 0.14(\operatorname{Stn} 7$ ) and $3.51 \pm 0.44$ and $6.78 \pm$ 0.53 (Stn 8) ( $\mu \mathrm{mol} \mathrm{min}^{-1} \mathrm{~g}^{-1}$ wet wt). The data presented are calculated for fresh tissue after applying a correction factor to values for frozen tissue of $\times 0.555$. Values presented are means \pm SEM. Groups of values were compared by 1 -way analysis of variance and $p<0.05$ was accepted as significant.

\section{RESULTS}

Selected contaminant data are presented in Table 1. A pollution gradient, with concentrations declining away from the coast, was evident in the total sediment fraction: total hydrocarbons, total metals and copper were highest at Stns $1 \& 3$, and declined through

Table 1. Levels of organic and inorganic chemical contaminants in sediments and liver of dab Limanda limanda from the North Sea. Calculated from Cofino et al. (1992). Single values except for total polychlorobiphenyls (PCBs) for Stns 3 to 9 which are means \pm SEM (SEM given in parentheses)

\begin{tabular}{|c|c|c|c|c|c|c|c|c|c|}
\hline \multirow[t]{2}{*}{ Contaminant } & \multicolumn{7}{|c|}{ German Bight stations } & \multicolumn{2}{|c|}{ Drilling site stations } \\
\hline & 1 & 3 & 5 & 6 & 7 & 8 & 9 & $\mathrm{~A}(0 \mathrm{~km})$ & $\mathrm{G}(5 \mathrm{~km})$ \\
\hline \multicolumn{10}{|l|}{ Sediment } \\
\hline Total hydrocarbons ${ }^{a}$ & 74 & 35 & 24 & 28 & 16 & 5 & 1 & 39 & 27 \\
\hline Copper ${ }^{b}$ & 17 & 8 & 6 & 3 & 2 & 3 & 1 & 4 & 3 \\
\hline Mercury ${ }^{c}$ & 438 & 123 & 27 & 14 & 6 & 6 & 6 & 14 & 10 \\
\hline Total metals ${ }^{d}$ & 177 & 113 & 61 & 40 & 28 & 18 & 8 & 47 & 49 \\
\hline \multicolumn{10}{|l|}{ Dab liver } \\
\hline Organochlorines ${ }^{e}$ & 428 & 401 & 385 & 339 & 423 & 361 & 289 & 262 & \\
\hline PCBs ${ }^{f}$ & - & $\begin{array}{l}117.6 \\
(11.1)\end{array}$ & $\begin{array}{c}41.2 \\
(3.5)\end{array}$ & $\begin{array}{l}21.1 \\
(1.2)\end{array}$ & $\begin{array}{l}15.3 \\
(0.4)\end{array}$ & $\begin{array}{c}15.6 \\
(1.1)\end{array}$ & $\begin{array}{l}23.1 \\
(3.1)\end{array}$ & 0.63 & 0.40 \\
\hline Copperg & - & 4.1 & 5.4 & 5.7 & 7.0 & 5.1 & 2.6 & 6.6 & 6.4 \\
\hline Mercury ${ }^{h}$ & - & 86 & 103 & 84 & 83 & 100 & 58 & 105 & 70 \\
\hline Total metals ${ }^{i}$ & - & 43 & 44 & 63 & 83 & 73 & 54 & 81 & 87 \\
\hline $\begin{array}{l}{ }^{a} \text { Determined by UV-flu } \\
{ }^{b} \mu g g^{-1} \text { dry wt } \\
{ }^{c} \mathrm{ng} \mathrm{g}^{-1} \text { dry wt } \\
{ }^{d} \text { Sum of arsenic, cadmi } \\
{ }^{e} \text { Sum of hexachlorocycl } \\
\mathrm{ng} \mathrm{g}{ }^{-1} \text { lipid } \\
{ }^{\mathrm{S}} \text { Sum of } 13 \text { PCB conger } \\
{ }^{g} \mu \mathrm{g} \mathrm{g}^{-1} \text { wet wt } \\
{ }^{\mathrm{h}} \mathrm{ng} \mathrm{g}^{-1} \text { wet wt } \\
{ }^{\mathrm{i}} \text { As for sediment total }\end{array}$ & $\begin{array}{l}\text { oresce } \\
\text { om, co } \\
\text { ohexa } \\
\text { ers (C } \\
\text { tetals i }\end{array}$ & $\begin{array}{l}\text { in } \mu \mathrm{gg}^{-} \\
\mathrm{r}, \text { mercur } \\
\mathrm{HCH}), \mathrm{h} \\
28,31,52 \\
\mathrm{~g} \mathrm{~g}^{-1} \text { we }\end{array}$ & $\begin{array}{l}\text { ry wt } \\
\text { lead and } \\
\text { chlorob } \\
01,105 \text {, }\end{array}$ & $\begin{array}{l}\text { ac in } \mu \mathrm{g} \\
\text { ene, } \mathrm{B}-\mathrm{-} \\
128,13\end{array}$ & $\begin{array}{l}\text { dry wt } \\
\text { H, lindan } \\
49,153,\end{array}$ & $\begin{array}{l}\text { aldrin, di } \\
6,170 \text { an }\end{array}$ & $\begin{array}{l}\text { rin, } \mathrm{DDE} \\
\text { 80) in } n\end{array}$ & $\begin{array}{l}\text { DDDs and } \\
-1 \text { wet wt }\end{array}$ & DT in \\
\hline
\end{tabular}


Table 2. Limanda limanda. Putative microsomal DTdiaphorase (dicumarol-inhibitable NADPH-dependent DCPIP reductase) activity in liver microsomes of dab along the chemical contaminant gradient in the German Bight of the North Sea. Values are means $\pm \operatorname{SEM}(\mathrm{n}=5$ to 15$)$ in $\mathrm{nmol}$ $\mathrm{min}^{-1} \mathrm{mg}^{-1}$ microsomal protein. Data in the same row sharing

the same superscript do not differ significantly ( $p>0.05)$

\begin{tabular}{|c|c|c|c|c|c|c|}
\hline 1 & 3 & 5 & $\begin{array}{l}\text { Strn } \\
6\end{array}$ & 7 & 8 & 9 \\
\hline $0.27^{\mathrm{ab}}$ & $0.78^{\mathrm{ab}}$ & b $\quad 1.26^{\mathrm{ab}}$ & b $\quad 0.08^{b}$ & $1.71^{\mathrm{dc}}$ & $=1.33^{d c}$ & $0.86^{\mathrm{ab}}$ \\
\hline \pm 0.15 & \pm 0.47 & \pm 0.64 & \pm 0.06 & \pm 0.44 & \pm 0.26 & \pm 0.42 \\
\hline
\end{tabular}

Stns 5 to 8 to reach a minimum at Stn 9. A gradient away from the coast was also found in the liver of dab for total PCBs, but it showed some differences from that of sediment hydrocarbons. Total PCBs were highesi in dab liver from Sin 3 ino data were available for Stn 1), but also relatively high at Stn 5 , and declined to similar values at Stns 6 to 9 . In dab liver the total organochlorine gradient was much less steep than that of PCBs, and no clear gradient existed for total metals and copper. Levels of organic and inorganic contaminants at the drilling site (Stn A) were either similar to or slightly higher than those at $5 \mathrm{~km}$, for both sediments and dab liver

Some similarities in the profiles of SOD and catalase were evident in the liver of dab along the pollution gradient (Fig. 1A, B). Both activities tended to be higher at Stns $1 \& 3$ ( $p<0.05$ only for catalase at Stn 3 ), lower at Stns 5 to 7 , and higher again at Stn 9. However, whereas catalase activity was unchanged between Stns 5 to 8 , SOD activity displayed a distinct U-shaped profile along the pollution gradient. GPX activity was highest at Stn 3 (no data were available for Stn 1) and low at all the other stations except for Stn 8 (Fig. 1C). Putative microsomal DT-diaphorase activity was similar at all stations, except for Stns $7 \& 8$ which were higher than Stn 6 (Table 2). The percentage inhibition by dicumarol of DCPIP reductase activity was generally not high and varied considerably between replicate biological samples at the same station, e.g. from $1.6 \pm 1.5 \%$ at $\operatorname{Stn} 6$ to $16.2 \pm 6.1 \%$ at $\operatorname{Stn} 1$
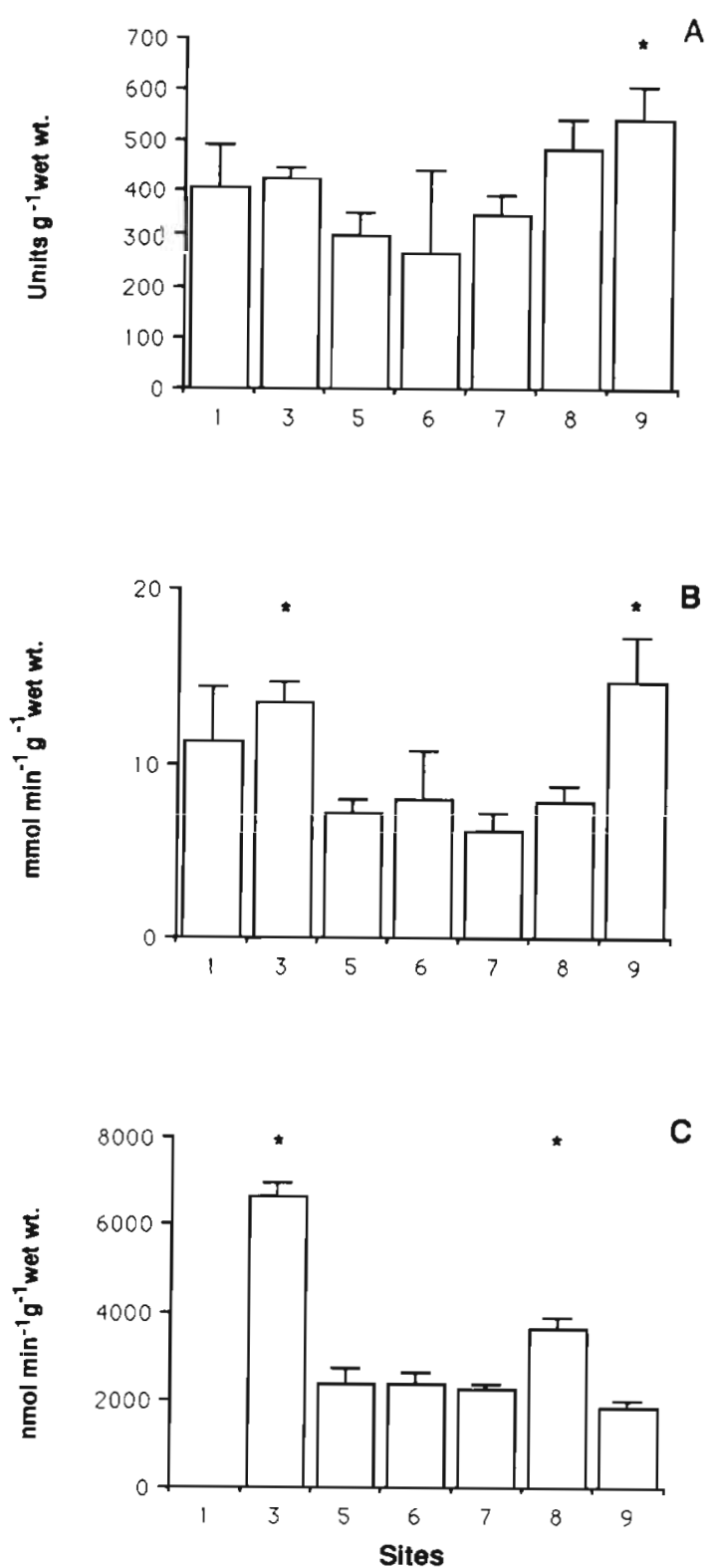

Fig. 1 Limanda limanda. Activities of superoxide dismutase (A), catalase (B) and glutathione peroxidase (C) in liver of dab from stations along a chemical contaminant gradient in the German Bight of the North Sea. See Table 1 for details of chemical gradient which decreased away from Stns $1 \& 3$. Values are means + SEM $(n=4$ to 18$) .^{\prime} p<0.05$ compared to Stns 5 or 7 . No data were obtained for glutathione peroxidase activity for Stn 1

Table 3. Limanda limanda. Superoxide dismutase (SOD) and putative microsomal DT-diaphorase (dicumarol-jnhibitable NADPH-dependent DCPIP reductase) activities in liver of dab from the vicinity of the disused drilling site off the Dutch coast in the North Sea. Values are means \pm SEM ( $n=3$ to 6). Data in the same row sharing the same superscript do not differ significantly $(p>0.05)$

\begin{tabular}{|lccc|}
\hline Variable & Stn & R $(15 \mathrm{~km})$ \\
\hline SOD (units $\mathrm{mg}^{-1}$ protein) & A $(0 \mathrm{~km})$ & $\mathrm{G}(5 \mathrm{~km})$ & $1.32 \pm 0.37^{\mathrm{a}}$ \\
Putative DT-diaphorase (nmol min ${ }^{-1} \mathrm{mg}^{-1}$ protein) & $4.80 \pm 2.15^{\mathrm{d}}$ & $1.56 \pm 0.42^{\mathrm{a}}$ & $1.3 \pm 0.4^{\mathrm{ab}}$ \\
\hline
\end{tabular}


Data for SOD and putative microsomal DTdiaphorase activities only were obtained for liver of dab from the vicinity of the abandoned drilling site (Table 3). The former is in SOD units per mg protein (data on wet weights of tissue were not available for these samples; cf. data of Fig. 1A). Mean SOD activity was higher at the drilling site itself ( $\operatorname{Stn} A$ ), but the difference was not statistically significant. Putative DTdiaphorase activity was higher at the drilling site $\operatorname{Stn} A$ than at $5 \mathrm{~km}$ (Stn G), but not at $15 \mathrm{~km}$ (Stn R) (Table 3). The putative DT-diaphorase activity at Stn. A was higher than any of those observed at Stns 1 to 9 along the pollution gradient (Tables $2 \& 3$; the percentage dicumarol inhibition of DCPIP reductase of the former was $36.7 \pm 11.4$ )

\section{DISCUSSION}

The induction of antioxidant enzymes has been studied in various prokaryotic, mammalian and other systems. Whereas SOD, catalase and GPX respond to a number of pro-oxidant conditions, including changing oxygen tension, induction of DT-diaphorase is mainly related to exposure to xenobiotics. Increases in mRNA, protein and/or catalytic activity of the former enzymes have been demonstrated in bacteria following exposure to the redox cycling xenobiotics menadione and paraquat (SOD) and $\mathrm{H}_{2} \mathrm{O}_{2}$ (catalase) (Storz et al. 1990), in mammalian systems with exposure to hyperoxia (SOD, catalase, GPX: Jones 1985), organophosphate pesticides (SOD: Capel 1988), the fungicide 2,3dichloro-1,4-naphthoquinone (SOD and catalase: Elliott \& Pardini 1988) and the endotoxin tumour necrosis factor (manganese-SOD: Shaffer et al. 1990), in insect larvae with increased intake of the dietary allelochemical quercetin (SOD: Pritsos et al. 1990), and in plants with exposure to paraquat or sulphur dioxide (Srivastave \& Tel-Or 1991). Decreases in gene expression and/or enzyme activity have also been seen in mammalian systems with various conditions, including age (SOD and catalase: Semsei et al. 1989), exposure to 2,3,7,8-tetrachlorodibenzo-p-dioxin (SOD: Stohs 1990), 2,3-dichloro-1,4-naphthoquinone (GPX: Elliott \& Pardini 1988) or hexa-chlorocyclohexane (lindane) (SOD and catalase: Videla et al. 1990), and carcinogenesis (variously, SOD, catalase and/or GPX: Vo et al 1988, Segura-Aguilar et al. 1990, Reiners et al. 1991). Mammalian DT-diaphorase is part of the gene battery that includes cytochrome P4501 A1 and is induced both by xenobiotics that bind to the Ah receptor and certain pro-oxidant xenobiotics that affect gene regulation via other mechanisms (Nebert et al. 1990). The xenobiotics include aromatic hydrocarbons, PCBs, organotins (Ariyoshi et al. 1991), and fungicides (Elliott \& Pardini
1988). Induction of DT-diaphorase by allelochemicals is seen in insects ( $\mathrm{Yu}$ 1987).

The same basic pro- and antioxidant processes observed in mammals exist in fish, including flatfish species (Shewfelt et al. 1981, Winston \& Di Giulio 1991 , Chipman et al. 1992). Evidence for this includes in vitro xenobiotic-stimulated oxyradical production and lipid peroxidation, the existence of antioxidant defences, and the detection of in vivo oxidative damage. However, the importance of these interactions, particularly the relationship of oxidative damage to disease and animal fitness, and the extent and specificity of induction of antioxidant enzymes, are much less welldefined. The guanine-derived lesion, 2,6-diamino-4hydroxy-5-formamido-pyrimidine, characteristic of hydroxyl radical attack, was present in DNA from neoplastic hepatic tissues of English sole Parophrys vetulus from a polluted environment, and a role for it in neoplasia has been proposed (Malins et al. 1990). The oxidised base 8-hydroxy-deoxyguanosine was also found in liver of Limanda limanda from the field (Chipman et al. 1992). Increases in activities of antioxidant enzymes with exposure to xenobiotics have been observed, but the responses have been variable. Dose-related increases in catalase activity (but no change in SOD or GPX activities) occurred in liver of the channel catfish Ictalurus punctatus exposed to bleached kraft mill effluent (Mather-Mihaich \& Di Giulio 1991), but no changes occurred in any hepatic antioxidant enzyme in the same species exposed to the organophosphorus herbicide S,S,S-tri-n-butyl phosphorotrithioate (Mather-Mihaich \& Di Giulio 1986). Similarly, SOD activity increased transiently in the erythrocytes of the common carp Cyprinus carpio morpha exposed to the redox cycling compound paraquat, but catalase and GPX activities did not change (Matkovics et al. 1987). Changes in antioxidant enzymes have also been observed in relation to contaminants identified in the pollution gradient studied here (see below).

The organic contaminant (hydrocarbon) and heavy metal gradient in total sediments was only partly reflected in the liver residue data. Although contaminant concentrations in sediments generally decreased steadily through Stns 1 to 9, tissue PCBs were high at Stn 5 and similar between Stns 6 to 9, and tissue metal levels did not change. The difference between these 2 indicators of chemical impact may be due to a number of factors, including bioavailability of the sediment-bound contaminants, their metabolism and elimination from the liver, the relative exposure levels of hydrocarbons and PCBs, and some movement of dab between stations (Rijnsdorp et al. 1992). The difference in chemical contamination at and $5 \mathrm{~km}$ from the abandoned drilling site (sediment or tissue levels) 
was small. However, detailed analysis of hydrocarbons by gas chromatography (GC) showed a larger difference of 18.1 and $0.4 \mu \mathrm{g} \mathrm{g}^{-1}$ dry weight at the drilling site Stn A and $5 \mathrm{~km}$ away, respectively (Cofino et al. 1992), compared to 39 and $27 \mu \mathrm{g} \mathrm{g}^{-1}$ dry weight measured by UV-fluorescence (Table 1).

Higher activities of catalase and GPX were observed near the coast (Stns $1 \& 3$ ) than at the centre of the pollution gradient, consistent with the greater exposure of dab to contaminants near the coast ( $p<0.05$ for both enzymes at Stn 3). Slight increases in SOD activity were indicated at Stns 1 \& 3 compared to Stns 5 to 7 , and at the drilling site Stn A compared to $5 \mathrm{~km}$ away, but in neither case were the differences statistically significant $(p>0.05)$. Of the chemical contaminants identified in sediment or liver, copper caused an increase in GPX activity and lipid peroxidation, but a decrease in catalase and SOD activities, in liver of the common carp Cyprinus carpio morpha, whereas zinc had relatively little effect, stimulating GPX activity slightly but decreasing catalase activity (Radi \& Matkovics 1988). Lipid peroxidation was increased in liver of the catfish Heteropneustes fossilis exposed to mercury (Bano \& Hasan 1989), and in liver microsomes of the striped mullet Mugil cephalus and the Atlantic croaker Micropogonias undulatus exposed to cadmium or PCBs (Aroclor 1254) (Wofford \& Thomas 1988). SOD activities in liver of spot Leiostomus xanthurus were higher at field stations contaminated with polynuclear aromatic hydrocarbons compared to unpolluted reference stations (Roberts et al. 1987). Following experimental exposure of Limanda limanda to sediment naturally contaminated with PCBs and PAHs for $80 \mathrm{~d}$, we have observed increases in hepatic catalase and SOD, but not GPX, activities (D. R. Livingstone \& A. Mathews unpubl.).

Somewhat surprisingly, increases in antioxidant enzyme activities were also seen towards the end of the pollution gradient, away from the coast. Catalase and SOD activities were elevated at Stn 9 (Dogger Bank) and GPX activity at Stn 8. In the case of SOD, a distinct U-shaped profile was apparent through Stns 1 to 9 . An increase in activity at Stn 9 compared to Stn 8 was also observed for 'hydrocarbon-inducible' cytochrome P4501A1 activity (7-ethoxyresorufin O-deethylase [ERODI) (Renton \& Addison 1992), and correlations between elevated hepatic SOD and aryl hydrocarbon hydroxylase (indicative of P4501A1) activities have been seen in field studies of Leiostomus xanthurus (Roberts et al. 1987). Several other variables also indicated increased biological effect on dab towards and/or at the Dogger Bank, e.g. muscle cholinesterases (Galgani et al. 1992) and aspects of pathology in both adults and embryos of dab (Moore 1992). The cause of these effects is unknown at present. In contrast to total sediment, the sieved sediment fraction $(<63 \mu \mathrm{m})$ showed a U-shaped profile in levels of total hydrocarbons, arsenic, cadmium and mercury (Cofino et al. 1992), but as the amount of this fraction decreased from $79.8 \%$ of the total sediment at Stn 1 to $7.5,3.3$ and $0.1 \%$ at Stns $7.8 \& 9$, respectively, a very specific size selection by dab would be necessary for this fraction to have any quantitative impact. Another difference between stations was that growth rates of dab were higher nearest to the shore and at Dogger Bank than at the intermediate stations (Rijnsdorp et al. 1992), but it seems unlikely that this would affect equally all the variables measured, particularly the pathology. Nutritional effects on antioxidant enzymes have been seen in fish but these have been very specific, e.g. GPX and SOD activities in rainbow trout Salmo gairdneri were reduced respectively by diets deficient in selenium (Bell et al. 1985) and manganese (Knox et ai. 1981). Nothing is known of the impact of dietary pro-oxidant chemicals on antioxidant enzymes in fish. Environmental variables that could be important with respect to antioxidant enzymes, particularly with respect to the distinct profile observed for SOD, are organic enrichment and/or the concentration of oxygen in the seawater. On several occasions between 1981 and 1983, dissolved oxygen was lower $(<40 \%$ saturation) in the region of the intermediate stations (ICES 1989). However, in the case of the carp Cyprinus carpio exposed to hypoxia, SOD activity was unaffected in the liver and increased in the gills (Vig \& Nemcsok 1989), i.e. the opposite effect to that observed for the intermediate stations relative to the inner and Dogger Bank stations. However, whatever the reasons for the putative altered oxidative stress along the pollution gradient, the lack of change in oxidised DNA bases (8-hydroxy-deoxyguanosine) in dab liver from the same stations (Chipman et al. 1992) shows the effectiveness of the antioxidant defences.

The data for putative DT-diaphorase activity are difficult to assess. No elevation was apparent at stations near to the coast, but an increased activity was found near to the disused drilling site. The degree of inhibition by dicumarol of NADPH-dependent DCPIP reductase activity in microsomes of Limanda limanda was generally low and very variable compared to another marine species, the mussel Mytilus edulis (Livingstone et al. 1989), indicating either a low activity of the enzyme, or a lack of specificity of the assay. Clearly, purification and/or characterisation of DTdiaphorase is a prerequisite for future studies of this enzyme. As in mammals, DT-diaphorase in fish may be co-induced with cytochrome P4501A1, but differences in gene regulation may also occur, as is the case for P4502B1 in fish (Stegeman 1989).

With respect to biomonitoring, the case for using 
antioxidant enzymes, either as biomarkers for pollution, or for focussing on mechanisms of pollutanttoxicity, is unresolved at present. Overall, the evidence from experimental exposures showing a relationship between contamination and effect is not convincing. Nothing is known of the genetic regulation of these enzymes in fish. However, catalase, GPX and possibly SOD activities in dab were higher at the more contaminated coastal stations, and the elevated activities at or near Stn 9 cannot be discounted because of the pollutant-related biological effects indicated by other biomarkers, including EROD activity. In contrast, the very distinct $U$-shaped profile for SOD activity along the gradient of decreasing chemical contamination suggests that other factors influence the enzyme. On theoretical grounds, DT-diaphorase seems to offer the greatest potential for a specific biomarker of chemical mediated oxidative stress, whereas catalase, SOD and GPX could respond to natural as well as man-made pro-oxidant conditions.

\section{LITERATURE CITED}

Ames, B. N. (1989). Mutagenesis and carcinogenesis: endogenous and exogenous factors. Environ. Molec. Mutagen. 14 (Suppl. 16): 66-77

Ariyoshi, T., Naritomi, Y., Machida, S., Arizono, K. (1991). Increase of DT-diaphorase activity and atrophy of thymus by organotin compounds. Bull. environ. Contam. Toxicol. 46: $100-107$

Aust, S. D., Morehouse, L. A., Thomas, C. E. (1985). Role of metals in oxygen radical reactions. Free Rad. Biol. Med. 1: 3-25

Bano, Y., Hasan, M. (1989). Mercury induced time-dependent alterations in lipid profiles and lipid peroxidation in different body organs of catfish Heteropneustes fossilis. J. environ. Sci. Health B42: 145-166

Bell, J. G., Cowey, C. B., Adron, J. W., Shanks, A. M. (1985). Some effects of vitamin $E$ and selenium deprivation on tissue enzyme levels and induction of tissue peroxidation in rainbow trout (Salmo gairdneri). Br. J. Nutr. 53: $149-157$

Benson, A. M., Hunkeler, M. J., Talalay, P. (1980). Increases of NAD(P)H: quinone reductase by dietary antioxidants. Possible role in protection against carcinogenesis and toxicity. Proc. natl Acad. Sci. U.S.A. 77: 5216-5220

Borg, D. C., Schaich, K. M. (1984). Cytotoxicity from coupled redox cycling of autoxidizing xenobiotics and metals. Israel J. Chem. 24: 38-53

Capel, I. D. (1988). Factors affecting antioxidant defense potential. In: Chow, C. K. (ed.) Cellular antioxidant defense mechanisms, Vol. II. CRC Press, Inc., Boca Raton, p. 191-215

Chipman, J. K., Marsh, J. W., Livingstone, D. R., Evans, B. (1992). Genetic toxicity in dab Limanda limanda from the North Sea. Mar. Ecol. Prog. Ser. 91: 121-126

Cofino, W. P., Smedes, F., de Jong, S. A., Abarnou, A., Boon, J. P., Oostingh, I., Davies, I. M., Klungsøyг, J., Wilhelmsen, S., Law, R. J., Whinnett, J. A., Schmidt, D., Wilson, S. (1992). The chemistry programme. Mar. Ecol. Prog. Ser. 91: $47-56$
Di Giulio, R. T., Washburn, P. C., Wenning, R. J., Winston, G. W., Jewell, C. S. (1989). Biochemical responses in aquatic animals: a review of determinants of oxidative stress. Environ. Toxicol. Chem. 8: 1103-1123

Elliott, A. J., Pardini, R. S. (1988). Modulation of hepatic cytochrome P-450 and DT-diaphorase by oral and subcutaneous administration of the pro-oxidant fungicide dichlone (2,3-dichloro-1,4-naphthoquinone). Bull. environ. Contam. Toxicol. 41: 164-171

Galgani, F., Bocquené, G., Cadiou, Y. (1992). Evidence of variation in cholinesterase activity in fish along a pollution gradient in the North Sea. Mar. Ecol. Prog. Ser. 91.77-82

Halliwell, B., Aruoma, O. 1. (1991). DNA damage by oxygenderived species. Its mechanism and measurement in mammalian systems. FEBS Letts. 281: 9-19

ICES (1989). Working group on biological effects of contaminants. ICES working paper

Jimenez, B. D., Oikari, A., Adams, S. M., Hinton, D. E., McCarthy, J. F. (1990). Hepatic enzymes as biomarkers: interpreting the effects of environmental, physiological and toxicological variables. In: McCarthy, J. F., Shugart, L. R. (eds.) Biomarkers of environmental contamination. Lewis Publishers, Boca Raton, p. 123-142

Jimenez, B. D., Stegeman, J. J. (1990). Detoxication enzymes as indicators of environmental stress in fish. In: Adams, S. M. (ed.) Biological indicators of stress in fish. Am. Fish. Soc. Symp. 8: 67-79

Jones, D. P. (1985). The role of oxygen concentration in oxidative stress: hypoxic and hyperoxic models. In: Sies, $H$. (ed.) Oxidative stress. Academic Press, New York, p. $151-195$

Kappus, H. (1986). Overview of enzymes involved in bioreduction of drugs and in redox cycling. Biochem. Pharmacol. 35: 1-6

Knox, D., Cowey, C. B., Adron, J. W. (1981). The effect of low dietary manganese intake on rainbow trout (Salmo gairdneri). Br. J. Nutr. 46: 495-501

Lawrence, R. A., Burk, R. F. (1976). Glutathione peroxidase activity in selenium-deficient rat liver. Biochem. Biophys. Res. Commun. 71. 952-958

Livingstone, D. R., Garcia Martinez, P., Michel, X., Narbonne, J. F., O'Hara, S., Ribera, D., Winston, G. W. (1990). Oxyradical production as a pollution-mediated mechanism of toxicity in the common mussel, Mytilus edulis L., and other molluscs. Funct. Ecol. 4: 415-424

Livingstone, D. R., Garcia Martinez, P., Winston, G. W. (1989). Menadione-stimulated oxyradical formation in digestive gland microsomes of the common mussel, Mytilus edulis L. Aquat. Toxicol. 15: 213-236

Lowry, O. H., Rosebrough, N. J., Farr, A. L., Randall, R. J. (1951). Protein measurement with the Folin phenol reagent. J. biol. Chem. 193: 265-275

Malins, D. C., Ostrander, G. K., Haimanot, R., Williams, P. (1990). A novel DNA lesion in neoplastic livers of feral fish: 2,6-diamino-4-hydroxy-5-formamidopyrimidine. Carcinogenesis 11. 1045-1047

Mather-Mihaich, E., Di Giulio, R. T. (1986). Antioxidant enzyme activities and malonaldehyde, glutathione and methemoglobin concentrations in channel catfish exposed to DEF and N-butyl mercaptan. Comp. biochem. Physiol. 85C: $427-432$

Mather-Mihaich, E., Di Giulio, R. T. (1991). Oxidant, mixedfunction oxidase and peroxisomal responses in channel catfish exposed to a bleached kraft mill effluent. Arch. environ. Contam. Toxicol. 20: 391-397

Matkovics, B., Witas, H., Gabrielak, T., Szabo, L. (1987). Paraquat as an agent affecting antioxidant enzymes of 
common carp erythrocytes. Comp. biochem. Physiol. 87C: $217-219$

McCord, J. M., Fridovich, I. (1969). Superoxide dismutase: an enzymatic function for erythrocuprein (hemocuprein). J. biol. Chem. 244: 6049-6055

Moore, M. N. (1992). Molecular and cellular pathology summary. Mar. Ecol. Prog. Ser. 91: 117-119

Nebert, D. W., Petersen, D. D., Fornace, A. J. Jr (1990). Cellular responses to oxidative stress: the [Ah] gene battery as a paradigm. Environ. Health Perspect. 88: $13-25$

Nishimoto, M., Roubal, W. T., Stein, J. E., Varanasi, U. (1991). Oxidative DNA damage in tissues of English Sole (Parophrys vetulus) exposed to nitrofurantoin. Chem.-Biol. Interact. 80: 317-326

Premereur, N., Van den Branden, C., Roels, F. (1986). Cytochrome P-450-dependent $\mathrm{H}_{2} \mathrm{O}_{2}$ production demonstrated in vivo. Influence of phenobarbital and allylisopropylacetamide. FEBS Letts. 199: 65-76

Preusch, P. C., Siegel, D., Gibson, N. W., Ross, D. (1991). A note on the inhibition of DT-diaphorase by dicoumarol. Free Rad. Biol. Med. 11.77-80

Pntsos, C. A., Ahmad, S., Elliott, A. J., Pardini, R. S. (1990). Antioxidant enzyme level response to prooxidant allelochemicals in larvae of the Southern Armyworm moth, Spodoptera eridania. Free Rad. Res. Commun. 9: $127-133$

Radi, A. A. R., Matkovics, B. (1988). Effects of metal ions on the antioxidant enzyme activities, protein contents and lipid peroxidation of carp tissues. Comp. biochem. Physiol. 90C: $69-72$

Reiners, J. J. Jr, Thai, G., Rupp, T., Cantu, A. R. (1991). Assessment of the antioxidant/prooxidant status of murine skin following topical treatment with 12-O-tetradecanoylphorbol-13-acetate and throughout the ontogeny of skin cancer. Part I: Quantitation of superoxide dismutase, catalase, glutathione peroxidase and xanthine oxidase. Carcinogenesis 12: 2337-2343

Renton, K. W., Addison, R. F. (1992). Hepatic microsomal mono-oxygenase activity and P450IA mRNA in North Sea dab Limanda limanda from contaminated sites. Mar. Ecol. Prog. Ser. 91: 65-69

Rijnsdorp, A. D., Vethaak, A. D., van Leeuwen, P. I. (1992). Population biology of dab Limanda limanda in the southeastern North Sea. Mar. Ecol. Prog. Ser. 91. 19-35

Roberts, M. H., Sved, D. W., Felton, S. P. (1987). Temporal changes in AHH and SOD activities in teral spot from the Elizabeth River, a polluted sub-estuary. Mar. environ. Res. 23: $89-101$

Segura-Aguilar, J., Cortes-Vizcaino, V., Llombart-Bosch, A., Ernster, L., Monsalve, E., Romero, F. J. (1990). The levels of quinone reductases, superoxide dismutase and glutathione-related enzymatic activities in diethylstilbestrol- induced carcinogenesis in the kidney of male Syrian golden hamsters. Carcinogenesis 11. 1727-1732

Semesi, I., Rao, G., Richardson, A. (1989). Changes in the expression of superoxide dismutase and catalase as a function of age and dietary restriction. Biochem. biophys. Res. Commun. 164: 620-625

Shaffer, J. B., Treanor, C. P., Vecchio, P. J. del (1990). Expression of bovine and mouse endothelial cell antioxidant enzymes following TNF-exposure. Free Rad. Biol. Med. 8: $497-502$

Shewfelt, R. L., McDonald, R. E., Hultin, H. O. (1981). Effect of phospholipid hydrolysis on lipid oxidation in flounder muscle microsomes. J. Food Biochem. 46: 1297-1301

Srivastave, A., Tel-Or, E. (1991). Effect of some environmental pollutants on the superoxide dismutase activity in Lemna. Free Rad. Res. Commun. 12-13: 601-607

Stebbing, A. R. D., Dethlefsen, V. (1992). Introduction to the Bremerhaven Workshop on Biological Effects of Contaminants. Mar. Ecol. Prog. Ser. 91: 1-8

Stegeman, J J. (1989). Cytochrome P450 forms in fish: catalytic, immunological and sequence similarities. Xenobiotica 19: 1093-1110

Stohs, S. J. (1990). Oxidative stress induced by 2,3,7,8-tetrachlorodibenzo-p-dioxin (TCDD). Free Rad. Biol. Med. 9: $79-90$

Storz, G., Tartaglia, L. A., Farr, S. B., Ames, B. N. (1990). Bacterial defenses against oxidative stress. Trends Genet. 6: 363-368

Videla, L. A., Barros, S. B. M., Junqueira, V. B. C. (1990). Lindane-induced liver oxidative stress. Free Rad. Biol. Med. 9: 169-179

Vig, E., Nemcsok, J. (1989). The effects of hypoxia and paraquat on the superoxide dismutase activity in different organs of carp, Cyprinus carpio L. J. Fish Biol. 35: 23-25

Vo, T. K.-O., Druez, C., Delzenne, N., Taper, H. S., Roberfroid, M. (1988). Analysis of antioxidant defense systems during rat hepatocarcinogenesis. Carcinogenesis 9: 2009-2013

Winston, G. W. (1991). Oxidants and antioxidants in aquatic animals. Comp. biochem. Physiol. 100C: 173-176

Winston, G. W., Di Giulio, R. T. (1991). Prooxidant and antioxidant mechanisms in aquatic organisms. Aquat. Toxicol. 19: $137-161$

Winterbourn, C. C. (1987). The ability of scavengers to distinguish $\mathrm{OH}$ production in the iron-catalysed Haber-Weiss reaction: comparison for four assays for $\mathrm{OH}$. Free Rad. Biol. Med. 3: 33-39

Wofford, H. W., Thomas, P. (1988). Effect of xenobiotics on peroxidation of hepatic microsomal lipids from striped mullet (Mugil cephalus) and Atlantic croaker (Micropogonias undulatus). Mar. environ. Res. 24: 285-289

Yu, S. J. (1987). Quinone reductase of phytophagous insects and its induction by allelochemicals. Comp. biochem. Physiol. 87B: 621-624 